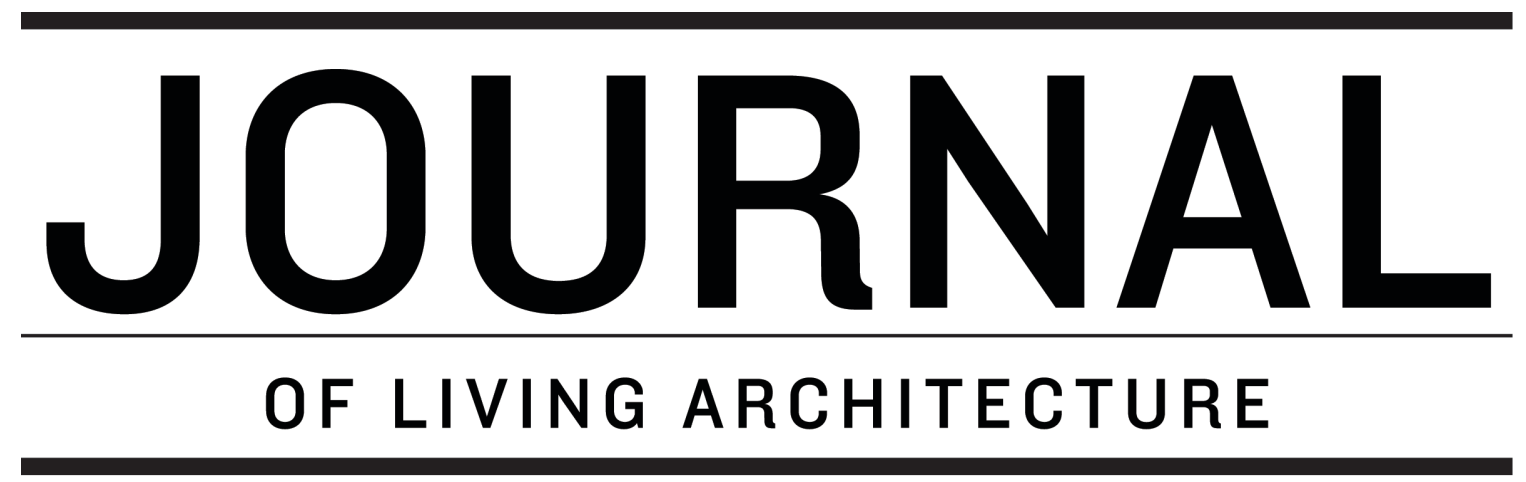

A GREEN INFRASTRUCTURE FOUNDATION PUBLICATION

\title{
Evaluation of a residential green roof system for stormwater runoff retention
}

\author{
Daniel Murphy ${ }^{1}$, Susan Morgan $^{2}$, Serdar Celik $^{3}$, Bill Retzlaff $^{4}$ \\ ${ }^{1}$ Graduate Student, Environmental Sciences Program, Southern Illinois University \\ ${ }^{2}$ Associate Dean Graduate School, Professor Civil Engineering, Southern Illinois University \\ ${ }^{3}$ Associate Professor Mechanical Engineering, Southern Illinois University \\ ${ }^{4}$ Associate Dean CAS, Distinguished Research Professor Biological and Environmental \\ Sciences, Southern Illinois University*Corresponding Author, wretzla@siue.edu
}

\begin{abstract}
While much green roof research has been directed towards commercial and industrial buildings, less is known about the sloped roofs of residential buildings. The purpose of this study was to evaluate a pitched residential green roof system and determine its ability to retain stormwater runoff. In order to do this, 18 shingled roof models were constructed on three slope angles $-1^{\circ}$, $20^{\circ}$ (5/12 pitch), and $40^{\circ}$ (10/12 pitch) of which 9 were randomly fitted with a modular green roof system across three replications. The $42.1 \%$ mean stormwater runoff retention for the green roof systems of was significantly greater than the $18.3 \%$ for shingled roof decks. A residential product (Steep Paks ${ }^{\circledR}$ ) performed within the conventional range of previous stormwater retention studies. The residential green roofs effectively reduced stormwater runoff during periods of light precipitation compared to periods of heavy precipitation. No difference was found in percent stormwater runoff retention between the three residential green roof slope angles.
\end{abstract}

Keywords: stormwater runoff, stormwater retention, sloped/pitched green roof, modular green roof system 


\section{INTRODUCTION}

Urban areas, especially those with dense human populations and a high percentage of impervious surfaces, face numerous environmental challenges. As world population and urban population density increase, finding solutions to environmental issues becomes increasingly imperative in order to maintain viable and habitable cities.

Due to high levels of impervious surface in urban areas, management of stormwater runoff is a major challenge. Impervious surfaces interrupt the natural hydrologic cycle of stormwater by disrupting infiltration and groundwater recharge. Excessive stormwater runoff can overwhelm drainage systems, especially when stormwater drains are combined with wastewater drains. Combined sewer overflows (CSO) result when the input of stormwater runoff exceeds the capacity of the sewer system and excess water is discharged into waterways. CSO events result in untreated sewage entering rivers and streams, which can harm wildlife, pollute drinking water supplies, and disrupt human recreation and industry (Bird et al. 2002, USEPA 2003). High levels of impervious surface can also result in an increased risk of flooding, especially when local waterways are already at capacity.

Green roofs - conventional roofs modified to support plant growth - are effective tools for managing stormwater runoff. For example, a properly designed green roof retains stormwater runoff during a rain event and releases it back into the environment at a lower flow rate with a delayed and reduced peak flow compared to a conventional roof (Bliss et al. 2009, Oberndorfer et al. 2007). Stormwater runoff that is retained in the substrate of a green roof after a rain event is released either through plant uptake and transpiration or by evaporation (Oberndorfer et al. 2007). Where green roofs can be installed on existing rooftops, they present an ideal stormwater runoff management tool in dense urban areas where available land area for retention ponds and cisterns is limited (Oberndorfer et al. 2007, Villarreal and Bengtsson 2005). Green roofs also provide benefits beyond the management of stormwater runoff, making them a more comprehensive solution to urban environmental challenges compared to other stormwater runoff management tools.

\section{Objectives and Hypotheses}

Most green roof research has been directed towards commercial and industrial buildings, often overlooking the potential that green roof technology may have in the residential sector and on smaller sloped roofs (Carey 2004, Dunnett et al. 2011). A GIS analysis of the city of Seattle, Washington demonstrated that residential roof surface area is five times greater than commercial roof surface area (Carey 2004), indicating that residential roofs should be a major focus of the green roof industry. Homeowners may benefit from having a green roof in two important ways: a reduction in stormwater runoff, which may result in reduced stormwater fees, and a reduction in energy demand. 
This current study involved the evaluation of a modular green roof system designed for residential roofs in order to determine a residential green roof's ability to retain stormwater. The green roof system was installed on roof models with one of three slope angles: $1^{\circ}, 20^{\circ}(5 / 12$ pitch), and $40^{\circ}$ (10/12 pitch). These slope angles were chosen because they are common roof pitches on residential buildings. Differences in the average stormwater runoff retention were compared between the green roof models and the shingled roof models and between three slope angles. The stormwater runoff retention of the green roof models were compared to those of the shingled roof models for the entire study period as well for the wettest and driest months of the study period. The green roof models were expected to consistently retain more stormwater runoff than the traditional, residential, shingled roof models. The $20^{\circ}$ and $40^{\circ}$ green roof models were expected to retain less stormwater runoff compared to the $1^{\circ}$ green roof model.

\section{METHODS AND MATERIALS}

\section{Experimental Set Up and Design}

A field experiment consisting of eighteen residential roof models was constructed at Southern Illinois University Edwardsville (SIUe). Roof decks were $1 / 2$ inch $(1.3 \mathrm{~cm})$ thick treated plywood measuring 8 -feet by 4 -feet $(2.44 \mathrm{~m}$ by $1.22 \mathrm{~m}$ ) with 2 -inch x 6 -inch lumber $(5.1 \mathrm{~cm}$ by $15.2 \mathrm{~cm})$ fastened around the bottom edge of each deck and three, 2-inch x 6-inch joists spaced across the underside of each deck at 2-feet $(61 \mathrm{~cm})$ spacing. Frames were constructed to raise the roof decks and position them at one of three slope angles: $1^{\circ}, 20^{\circ}$ (5/12 pitch), and $40^{\circ}$ (10/12 pitch). Six roof decks were positioned at each of the slope angles (Fig. 1). The legs of the frames supporting the roof decks were 4-inch $\mathrm{x}$ 4-inch lumber $(10.2 \mathrm{~cm}$ by $10.2 \mathrm{~cm})$. Half-inch thick treated plywood was fastened to the base of the legs to secure them in place. The plywood was

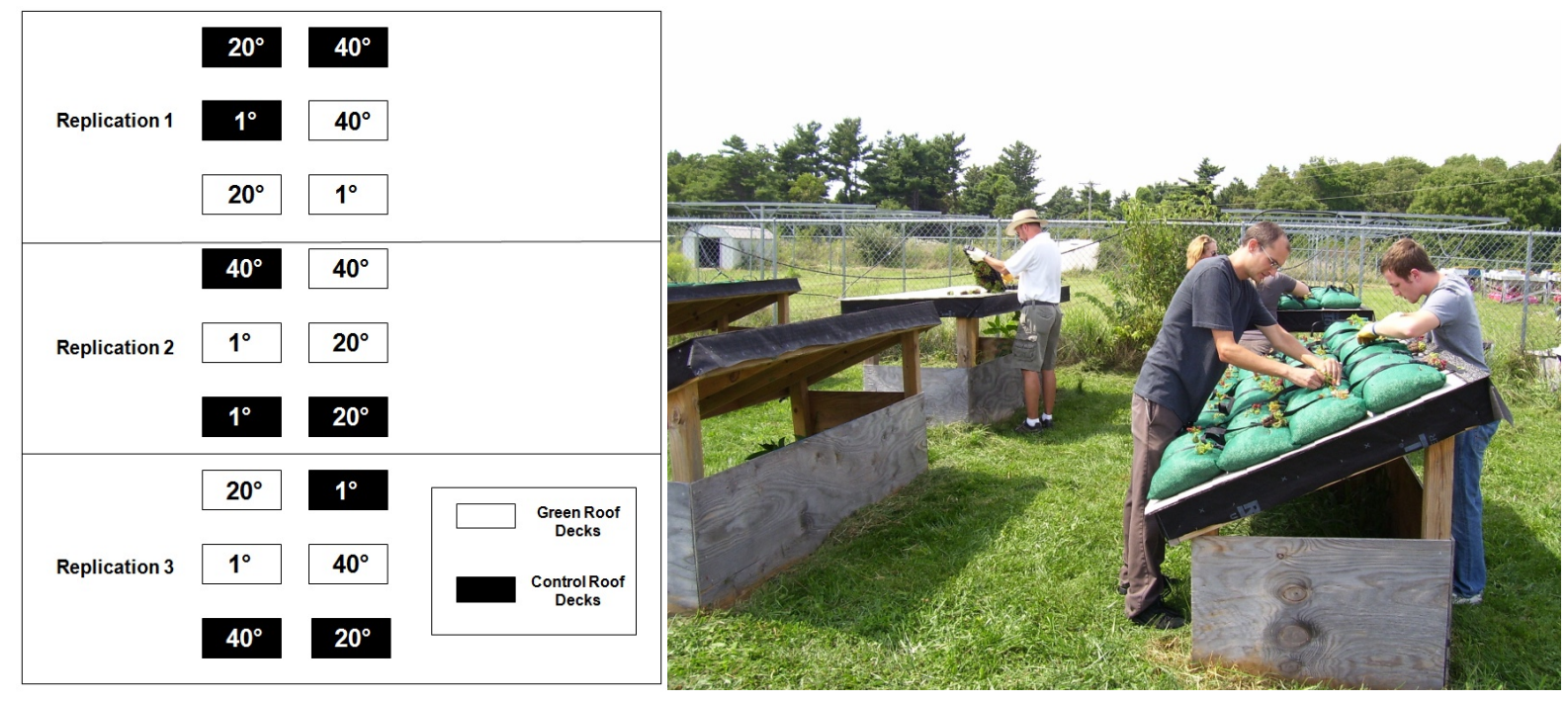

Figure 1. Experimental layout of residential roof models at the environmental sciences field site at Southern Illinois University Edwardsville in Edwardsville, Illinois. 
cut to a height of 24 -inches $(61 \mathrm{~cm})$ and fastened to the back and both sides of the frame, leaving the top portion open to permit access to the undersides of the roof decks for thermal evaluation. (Not reported on here.)

Upper surfaces of all roof decks were covered in roofing paper and shingled with Corning Shasta White composite asphalt shingles. Nine of the 18 roof models ( 3 models at each of the 3 slope angles) were fitted with a modular green roof system. The green roof modules were high-density polyethylene, knit fabric bags called Steep Paks ${ }^{\circledR}$, designed and manufactured by Green Roof Blocks $^{\mathrm{TM}}$ (St. Louis, MO). They were 10-inches wide and 32-inches long $(25.4 \mathrm{~cm}$ by $81.3 \mathrm{~cm})$ and filled to a maximum depth of 5-inches $(12.7 \mathrm{~cm})$ with blended arkalyte, consisting of $80 \%$ arkalyte by volume (Bussen Quarries, St. Louis, MO; $6 \mathrm{~mm}-9 \mathrm{~mm}$ expanded clay aggregate) and 20\% composted pine bark by volume (River City Landscape, Sauget, IL). Twelve Steep Paks ${ }^{\circledR}$ modules (four rows with three modules in each row) were fastened to each of the nine roof decks with nylon anchor straps integrated into the shingles and tacked to the roof decks.

All of the roof models were oriented so that the roof surfaces were facing roughly south $\left(215^{\circ}\right.$ $\mathrm{SW}$ ) in order to maximize sun exposure. The eighteen roof models were divided equally into three replications in a completely randomized experimental design with each replication including two roofs at each slope angle, one of which was fitted with Steep Paks ${ }^{\circledR}$ green roof modules and the other left as a conventional (uncovered) shingled roof (Fig. 1).

\section{Plant Material and Plant Coverage}

Mixed plugs (size 72) of seven Sedum species ( $S$. kamtschaticum, S. reflexum, S. sexangulare, $S$. album, S. spurium, S. floriferum 'Weihenstaphaner Gold', and S. immergrunchen) (Jost

Greenhouses, Des Peres, MO) were planted in the Steep Paks ${ }^{\circledR}$ on September 4, 2009. Four small holes were cut in the top of each module, evenly spaced across the length of the module, in order to plant the plugs. Approximately 8 grams of Earthworks ${ }^{\mathrm{TM}}$ natural organic fertilizer with an N-P$\mathrm{K}$ rating of 5-4-5 was placed in each hole before planting. The plants were irrigated 1 to 2 times a week for two months to aid establishment. Plants lost due to deer browsing and winterkill were replaced in September 2010. Woodace ${ }^{\circledR}$ long-term fertilizer with an N-P-K rating of 18-5-10 was broadcast evenly across the Steep Paks ${ }^{\circledR}$ by hand on April 2, 2010, September 19, 2010 and March 24, 2011.

Plant coverage was quantified using a modified dot grid system. The dot grid measured 20inches by 16 -inches $(50.8 \mathrm{~cm}$ by $40.6 \mathrm{~cm})$ and had 80 open circles (10 rows of 8 circles each) that were 1.5-inches $(3.8 \mathrm{~cm})$ in diameter. The center of each green roof model was divided into six equal sections of 20 inches by 16 inches, the size of the dot grid. The dot grid was placed over each section, and open circles in the dot grid were counted. Circles were considered open if less than $50 \%$ plant material was showing. Percent plant coverage was calculated by using the equation:

$$
[(80-\# \text { of open circles }) / 80] * 100
$$


Plant coverage was measured once during the second half of each month between March and May 2011.

\section{Stormwater Runoff Data Collection}

Aluminum gutters were installed on each of the roof models, and eighteen 55-gallon (208 L), plastic, food grade barrels were cut in half, fitted with plywood lids, and placed at the ends of each of the gutters in order to collect stormwater runoff. Downspouts were attached to the ends of each of the gutters and directed into the barrels through a small notch in the plywood lids. Two $12 \mathrm{~cm}$ glass rain gauges were installed on roof models at the field site to monitor the amount of precipitation throughout the study period. During periods of snowfall, precipitation data was obtained from the SIUe Wastewater Treatment Plant (located $1 \mathrm{~km}$ from the field site). Ten-inches $(25.4 \mathrm{~cm})$ of snow was considered equivalent to 1 -inch $(2.5 \mathrm{~cm})$ of precipitation. After rain events, the depth of runoff in each barrel was measured using a metric ruler and then converted into liters using regression equations for runoff volume calculated previously for each of the barrels.

Percent reduction in stormwater runoff was determined by subtracting the amount of rainfall collected in the barrels from the amount of precipitation that fell on the roof deck and then dividing that by the amount of precipitation that fell on the roof deck. The amount of precipitation collected in the rain gauges was used to determine the amount of rain that fell on each roof deck. Shingle overhang was included in the roof deck surface area. Because slopes reduce the horizontal area upon which rain falls, the effective surface area was calculated for the $20^{\circ}$ and $40^{\circ}$ roof decks. The effective roof surface areas for the $1^{\circ}, 20^{\circ}$, and $40^{\circ}$ roof decks were $33.69-\mathrm{ft}^{2}\left(3.13 \mathrm{~m}^{2}\right), 31.64-\mathrm{ft}^{2}\left(2.94 \mathrm{~m}^{2}\right)$, and $27.53-\mathrm{ft}^{2}\left(2.56 \mathrm{~m}^{2}\right)$, respectively.

\section{Study Period and Data Analysis}

Runoff was measured 43 times between September 24, 2010 and May 29, 2011. Several of the measurements may have included multiple rain events because it was not always possible to take measurements between events; however, the barrels were never permitted to overflow between measurements. Analyses were conducted using total rainfall collected over the entire study period, as well as for the wettest month (April 2011) and the driest month (December 2010) of the study period. A one-way ANOVA for a completely randomized experimental design with three replications was used to evaluate differences between the green roof decks and the shingled roof decks and between the three slope angles. A Tukey's post-hoc test was used to rank the differences between the treatments at an alpha level of 0.05 for each analysis, and an analysis of covariance was used to determine if percent plant coverage influenced stormwater runoff retention during March through May 2011 (Proc GLM, SAS version 9.3). 


\section{RESULTS}

\section{Total Study Period}

Total precipitation that fell during the study period (September 24, 2010 to May 29, 2011) was $87.8 \mathrm{~cm}$ (Fig. 2). Green roof decks had means for stormwater runoff retention of $42.1 \%$ compared to $18.3 \%$ observed for the shingled roof decks (Fig. 3a). No differences appeared for percent retention between the three slope angles of the green roof decks; neither did differences appear for percent retention between the three slope angles of the shingled roof decks (Fig. 3b-c). When the slope angles of the green roof decks were compared separately with their shingled roof deck counterparts, each green roof slope angle deck had a greater mean stormwater runoff retention compared to the shingled roof decks (Fig. 3d-f).

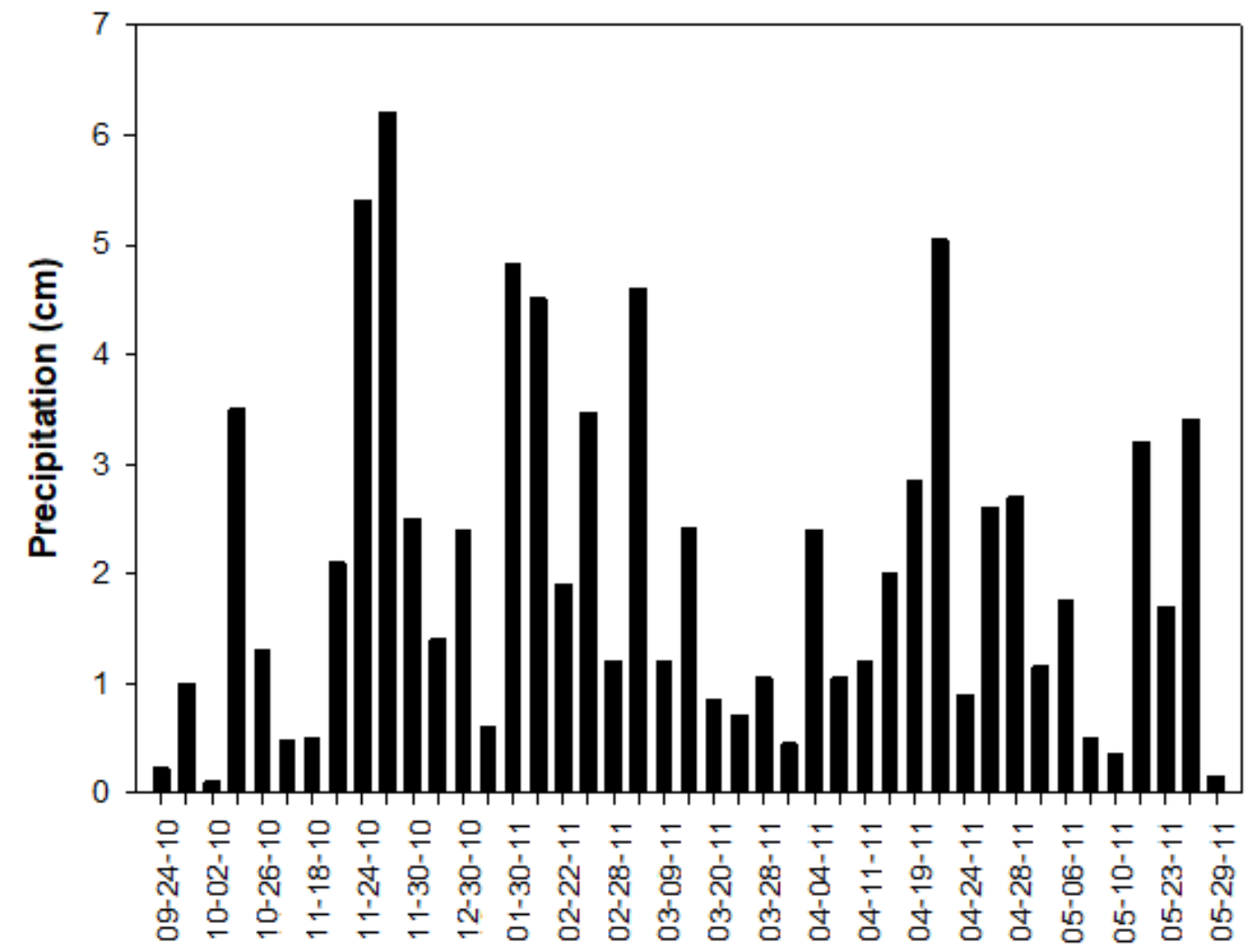

Figure 2 Precipitation recorded at the field site at each stormwater runoff measurement.

\section{Wettest Month of Study Period}

The wettest month of the study period was April 2011 with $20.8 \mathrm{~cm}$ (8.2 in) total precipitation collected over nine measurement dates. During this period the mean stormwater runoff retention of green roof decks was $35.8 \%$ compared to $15.4 \%$ observed for the shingled roof decks (Fig. 4a). No significant differences in percent retention existed between the three slope angles of the green roof decks, nor did differences exist between the slope angles of the shingled roof decks (Fig. 4b-c). When the slope angles of the green roof decks were compared separately with their shingled roof deck counterparts, the $20^{\circ}$ and $40^{\circ}$ green roof decks had greater mean stormwater 
runoff retention compared to the shingled roof decks; however, there was no difference between the green roof decks and the shingled roof decks in the $1^{\circ}$ slope angle treatment (Fig. $4 \mathrm{~d}-\mathrm{f}$ ).

\section{Driest Month of Study Period}

December 2010, the driest month of the study period had $4.4 \mathrm{~cm}$ (1.7 in) precipitation collected over three measurement dates. During this period, the mean stormwater runoff retention of green roof decks was $51.6 \%$ compared to $19.7 \%$ for the shingled roof decks (Fig. 5a).
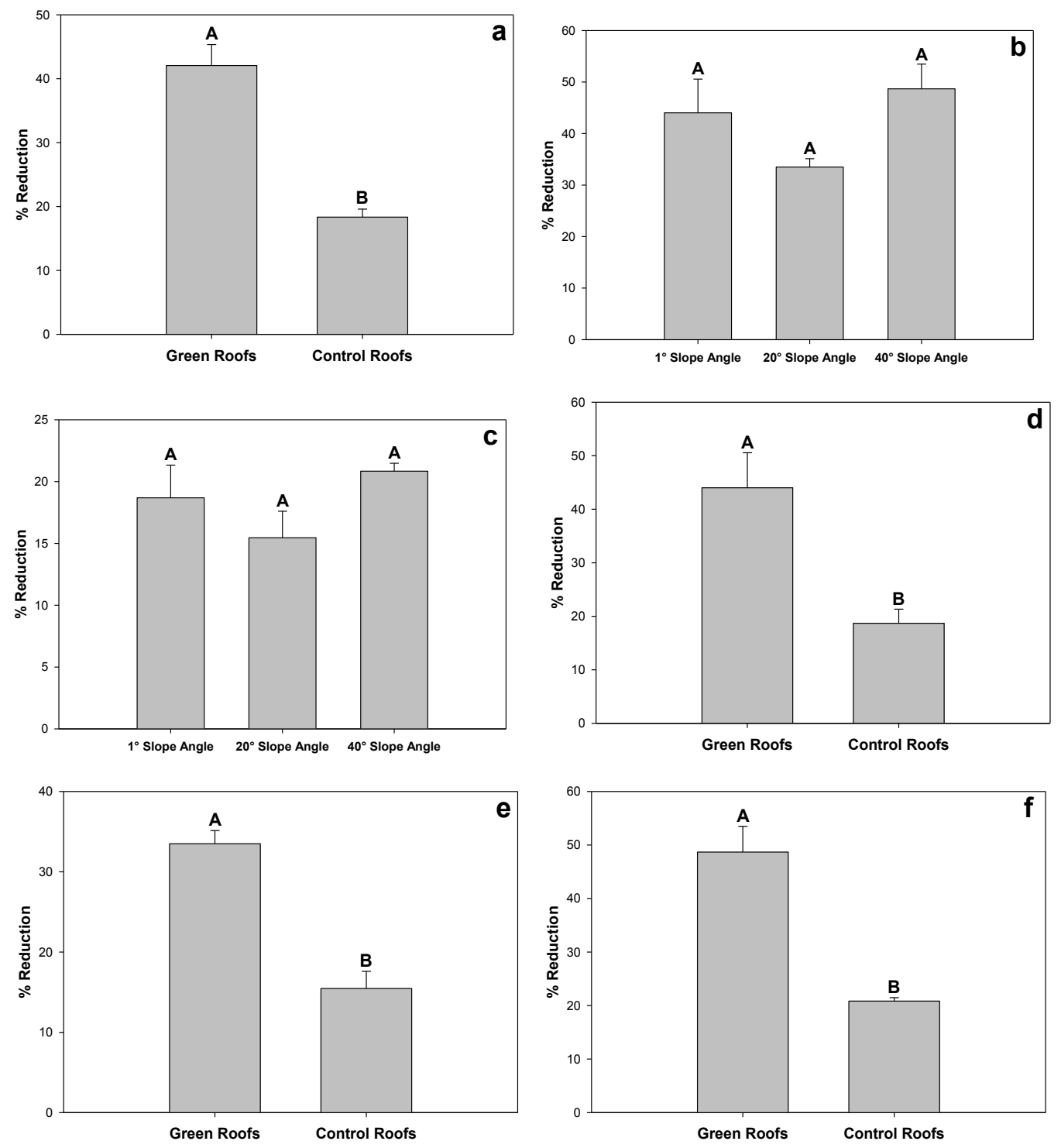

Figure 3. Mean stormwater runoff reduction values (\%) for study period 9/24/10 - 5/29/11. (a) compares green roof decks with control roof decks, (b) compares the slope angles of the green roof decks, (c) compares the slope angles of the control roof decks, (d-f) compares the $1^{\circ}, 20^{\circ}$, and $40^{\circ}$ slope angles respectively between the green roof decks and control roof decks. Bars within a sub-figure with different letters are significantly different $(\mathrm{p}<0.05)$. Error bars represent +1 se. 

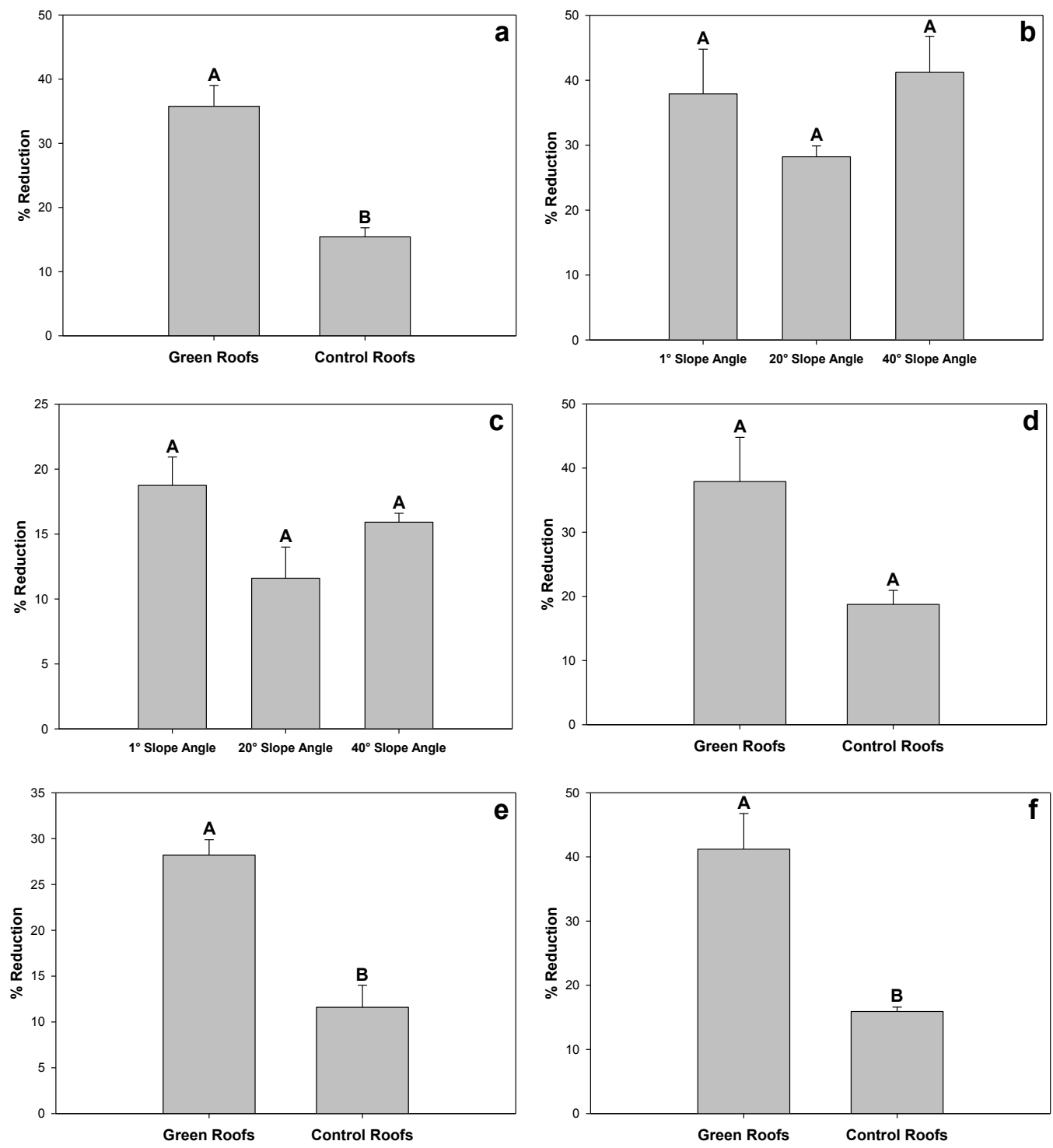

Figure 4. Mean stormwater runoff reduction values (\%) for April 2011. (a) compares green roof decks with control roof decks, (b) compares the slope angles of the green roof decks, (c) compares the slope angles of the control roof decks, (d-f) compares the $1^{\circ}, 20^{\circ}$, and $40^{\circ}$ slope angles respectively between the green roof decks and control roof decks. Bars within a subfigure with different letters are significantly different $(p<0.05)$. Error bars represent +1 se.

No significant differences in percent retention existed between the three slope angles of the green roof decks, nor did significant differences exist between the three slope angles of the shingled roof decks (Fig. 5b-c). When the slope angles of the green roof decks were compared separately with their shingled roof deck counterparts, each green roof slope angle had significantly greater mean stormwater runoff retention compared to the shingled roof decks (Fig. 5d-f). 

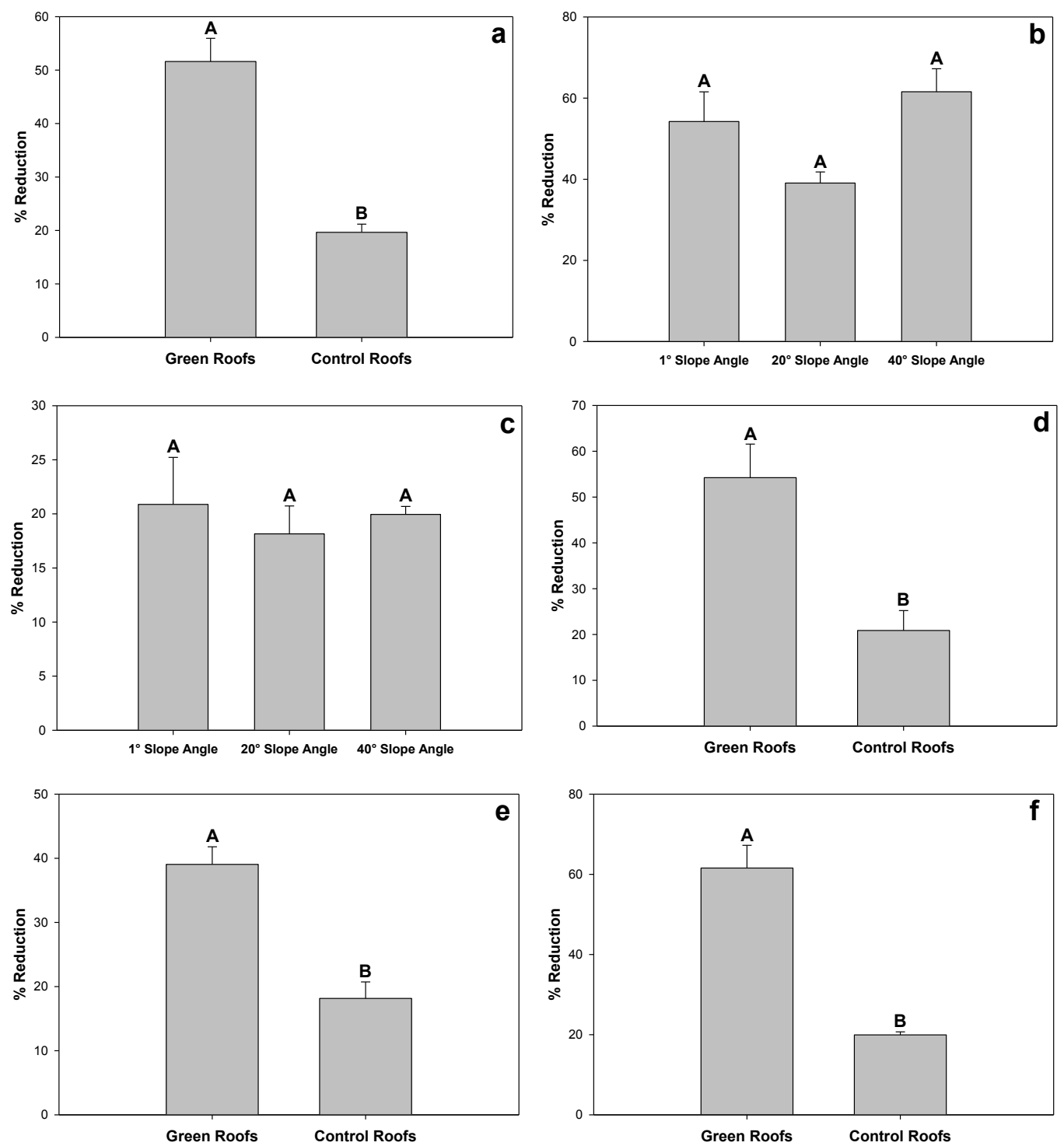

Figure 5. Mean stormwater runoff reduction values (\%) for December 2010, where (a) compares green roof decks with control roof decks, (b) compares the slope angles of the green roof decks, (c) compares the slope angles of the control roof decks, (d-f) compares the $1^{\circ}, 20^{\circ}$, and $40^{\circ}$ slope angles respectively between the green roof decks and control roof decks. Bars within a subfigure that have different letters are significantly different $(p<0.05)$. Error bars represent +1 se.

\section{Plant Coverage}

Percent plant roof coverage on the green roof models was measured in March, April and May 2011 (Fig. 6). In each month, the $1^{\circ}$ green roof decks had greater percent plant coverage than the other slope angles. No significant differences in percent plant coverage existed between the $20^{\circ}$ and $40^{\circ}$ green roof decks. An analysis of covariance was conducted to determine if percent plant coverage influenced percent stormwater runoff retention during the months of March, April, or May 2011 for any of the green roof slope angles. No correlation between plant percent roof coverage and stormwater retention was found during any of the months analyzed $(p<0.05)$. There 
were no differences between the mean stormwater runoff retention of the three green roof slope angles in April or May. However, in March, the $40^{\circ}$ green roof decks had a greater mean stormwater runoff retention (53.2\%) compared to the $20^{\circ}$ green roof decks (32\%). Despite the greatest percent plant coverage, the $1^{\circ}$ roof decks did not have a greater average runoff retention compared to the other two slope angles in any of the three months analyzed (Fig. 7).

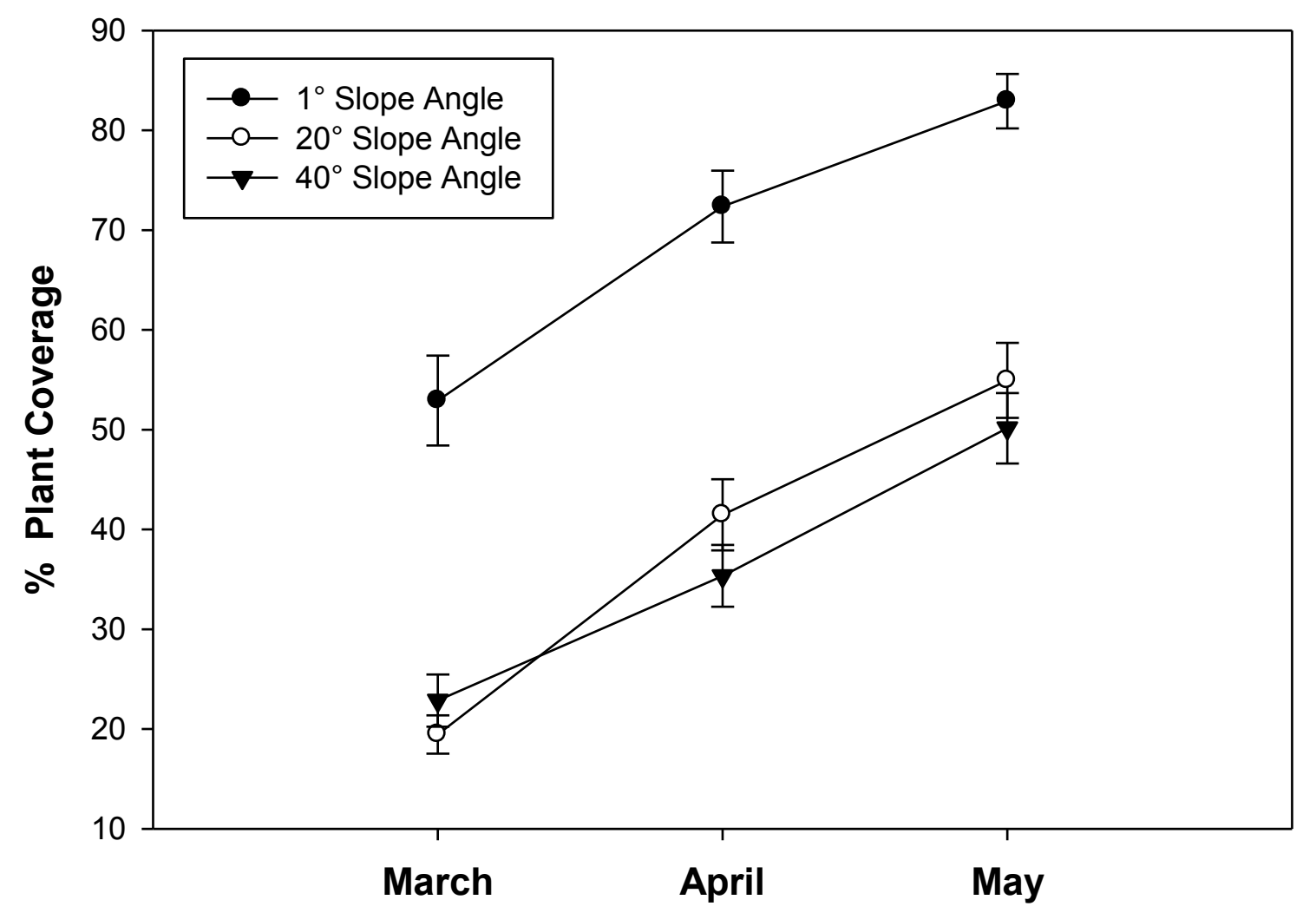

Figure 6. Mean percent plant coverage on green roof decks for each slope angle during March May 2011. On average the green roof models at the $1^{\circ}$ slope angle had significantly greater percent roof coverage than the green roof models at the $20^{\circ}$ and $40^{\circ}$ slope angles on each measurement date, and there were no differences between the $20^{\circ}$ and $40^{\circ}$ slope angles for any of the measurement dates $(\mathrm{p}<0.05)$. Error bars represent \pm 1 se. 


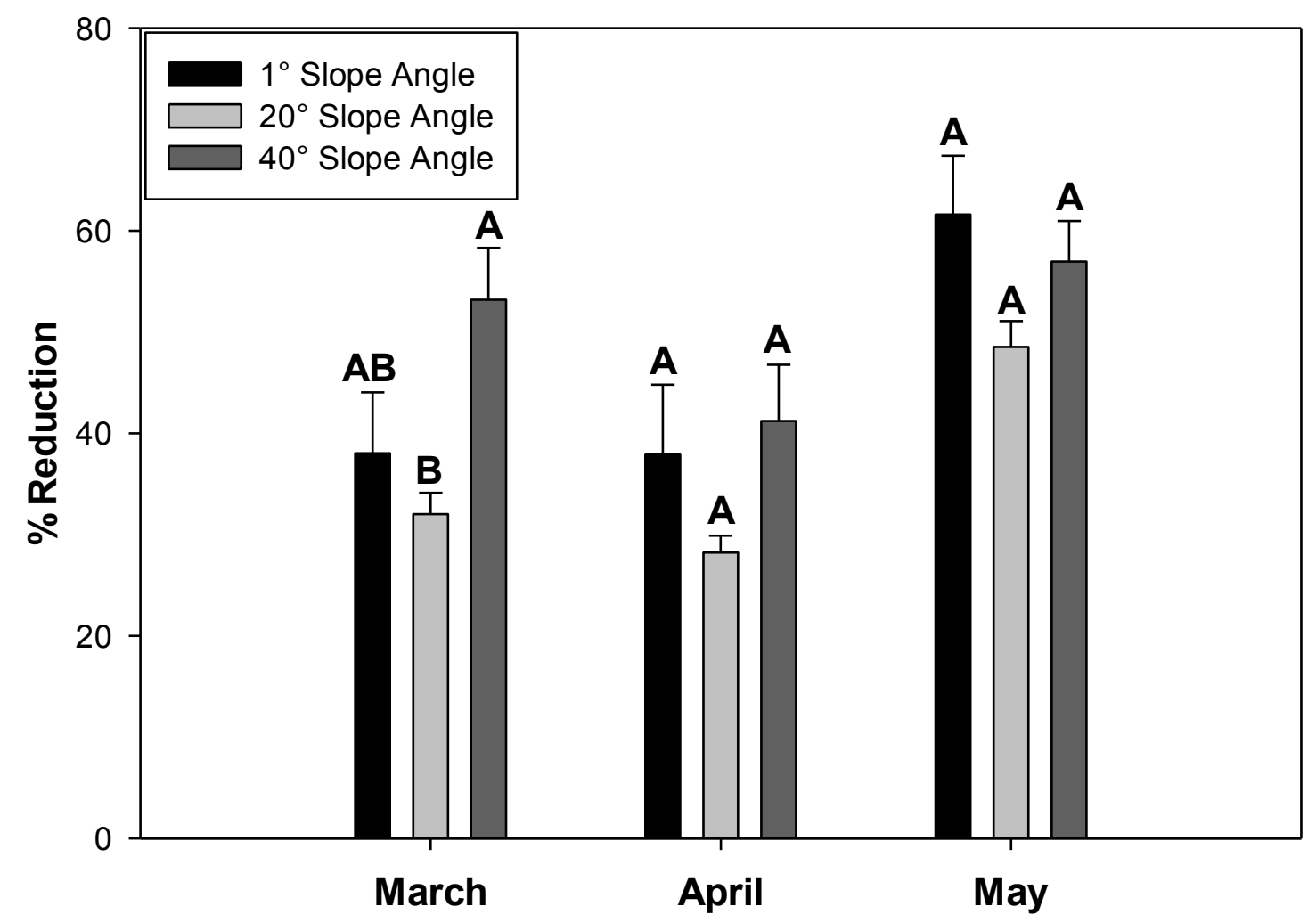

Figure 7. Mean stormwater runoff reduction values (\%) of green roof decks at $1^{\circ}, 20^{\circ}$, and $40^{\circ}$ slope angles for March - May 2011. Bars with different letters within each month are significantly different $(p<0.05)$. Error bars represent +1 se.

\section{DISCUSSION}

The residential green roof system evaluated in this study produced a mean stormwater runoff retention of $42.1 \%$ during the study period; the control (shingled) roofs had a mean stormwater runoff retention of $18.3 \%$. These results are comparable to a one-year evaluation in Atlanta, GA in which a modular green roof system had an average stormwater runoff retention value of $43 \%$ (Carter and Butler 2008). In a review of 18 publications by Mentens et al. (2006), extensive green roofs with a substrate layer of $10 \mathrm{~cm}$ were found to have an average annual stormwater runoff retention value of $45 \%$.

\section{Light Rain Events vs. Heavy Rain Events}

Simmons et al. (2008) demonstrated that stormwater runoff retention can vary greatly depending on the green roof system and the amount of rainfall; six different green roof systems had stormwater runoff retention values that varied between $8 \%$ and $88 \%$ during three rain events of varying amounts. Several other studies have demonstrated that green roof systems retain a greater percentage of stormwater runoff from light rain events compared to heavy rain events (Bliss et al. 2009, Getter et al. 2007, VanWoert et al. 2005, Villarreal and Bengtsson 2005). This 
result is because the substrate becomes saturated during periods of heavy rain and can no longer retain precipitation. The antecedent moisture content of the green roof growth media also affects runoff retention especially if the media is saturated (Bliss et al. 2009, Getter et al. 2007, Villarreal and Bengtsson 2005).

The residential green roof decks in this study similarly had greater mean stormwater runoff retention values in the driest month (December 2010) compared to the wettest month (April 2011). In December, stormwater runoff was measured three times; the amount of precipitation recorded at the field site before each of these measurements was $1.4 \mathrm{~cm}, 2.4 \mathrm{~cm}$, and $0.6 \mathrm{~cm}$ (Fig. 2). The green roof decks averaged $51.6 \%$ stormwater runoff retention during that month (Fig. 5a). In April, stormwater runoff was measured nine times; the amount of precipitation recorded at the field site was $2 \mathrm{~cm}$ or greater for six of the nine observations, and the largest amount of precipitation recorded was $5.05 \mathrm{~cm}$ (Fig. 2). The green roof decks averaged only $35.8 \%$ stormwater runoff retention of during that month (Fig. 4a). Frequent and heavy rain events likely reduced the ability of the green roof modules to retain stormwater runoff. Additionally, much of the precipitation collected at the field site in December came in the form of snowfall, which may be easier for the green roofs to retain compared to rainfall because melting snow slowly enters the substrate.

In April 2011, the mean stormwater runoff retention of the $1^{\circ}$ slope angle was not different between the green roof decks and the shingled roof decks (Fig. 4d). Due to its lack of pitch, $1^{\circ}$ green roofs remained saturated longer than the $20^{\circ}$ and $40^{\circ}$ green roof decks and were, therefore, unable to retain more stormwater runoff than the $1^{\circ}$ shingled roof decks. In a preliminary study by Mentens et al. (2003), slope angle and roof orientation were demonstrated to influence the evaporation rate on a green roof. All of the roof decks in this study faced south, where exposure to the sun is the greatest. This orientation should result in higher evaporation rates, especially for green roof decks at steeper slope angles.

\section{Plant Roof Coverage}

Percent plant roof coverage was found to have no influence on the mean stormwater runoff retention of the green roof decks in this study. Percent plant coverage was measured March through May 2011, with the $1^{\circ}$ roof decks having the greatest average percent plant coverage during each month $(52.9 \%, 72.4 \%$, and $82.9 \%$, respectively) (Fig. 6). Despite having greater percent plant coverage, the $1^{\circ}$ green roof decks did not have greater average stormwater runoff retention during March through May 2011 (Fig. 7). In April and May, there were no differences in the mean stormwater runoff retention of all three slope angles of the green roof decks, and in March, the $40^{\circ}$ green roof decks had a greater mean stormwater runoff retention than the $20^{\circ}$ green roof decks, but the mean stormwater runoff retention of the $1^{\circ}$ green roof decks was not different from either one of the other slope angles (Fig. 7). 


\section{The Effects of Slope}

Few studies have observed stormwater runoff retention on green roofs with pitches as steep as the model roof systems observed in this study. A study by Getter et al. (2007) involved green roof models set at four slopes ranging from $2 \%$ to $25 \%$, and it was determined that stormwater runoff retention decreased as slope increased. Getter et al, (2007) further explained variation was due to the separation of rain events, which when left combined can mask slope effects on retention. These results were compared to two German studies that found no differences in percent retention between green roof slopes ranging from $2 \%$ to $58 \%$; however, the (German) green roof models were saturated at the time of testing, and they were not observed under natural weather conditions (Liesecke 1998, Schade 2000). VanWoert et al. (2005) compared the stormwater runoff retention values of green roof models at $2 \%$ and $6.5 \%$ slopes and determined that the steeper slope retained less stormwater runoff. Villarreal and Bengtsson (2005) compared the stormwater runoff retention values of $2^{\circ}, 5^{\circ}, 8^{\circ}$, and $14^{\circ}$ green roof models and found that, while the unit hydrographs of each of the slope angles were similar (except for some variation in peak flow), the stormwater runoff retention decreased as slope increased.

Different from previous findings, the current study found no significant differences in the mean stormwater runoff retention of the three residential green roof slope angles tested. The $40^{\circ}$ green roof decks had a mean stormwater runoff retention of $48.7 \%$, and were not found to be significantly different from the other two slope angles $\left(1^{\circ}=44 \%\right.$ and $20^{\circ}=33.5 \%$ retention respectively) (Fig. 3b). Similarly, there were no differences in the mean stormwater runoff retention of the three green roof slope angles during the wettest and driest months of the study (Fig. 4b and 5b). This slightly unexpected finding may be explained, in part, by the brief eightmonth data study period during a cold-season time period with less than full plant coverage (Fig. 6). Stormwater retained by green roofs either evaporates or is used by the plants and water from the growth media is thus transpired (Berndtsson 2010). During the growing season, evapotranspiration is much greater and the green roof retention capacity regenerates faster (Mentens et al. 2006, Villarreal 2007). Monitoring the stormwater retention by our sloped roof models during a full growing season period may have produced similar retention findings, i.e. that sloped roofs retain less stormwater than "flat" roofs. Additional factors that may have influenced the retention via the differentially sloped decks include: the roof decks were placed in only one orientation (southwest exposure), there were only three replicate roof models, and the study period did not include summer (growing season) months.

\section{CONCLUSION}

This study demonstrates that residential green roof models (Steep Paks ${ }^{\circledR}$ ) were more effective at retaining stormwater runoff compared to traditional, shingled roof decks. Residential green roof decks had means for stormwater runoff retention of $42.1 \%$ for the total study period. The green roof modules were more effective at reducing stormwater runoff during periods of light precipitation (51.6\% runoff reduction) compared to periods of heavy precipitation (35.8\% runoff reduction). 
No difference in stormwater runoff retention was found between the three slope angles of the green roofs in the total study period analysis. Other studies have demonstrated that stormwater runoff retention decreases as slope angle increases. The roof models in this study were placed at a single orientation, and rainfall direction, intensity, and duration could have played a role in the amount of runoff retained on the roof models. Further investigation during a full growing season would be necessary in order to better determine the effects of slope on stormwater runoff reduction of the green roof modules.

Percent plant roof coverage on these residential green roof models was found to have no influence on stormwater runoff reduction. However, heavy deer browsing occurred along the lower edges of green roof models on the $20^{\circ}$ and $40^{\circ}$ roof decks in the first year of the study period, and the $1^{\circ}$ roof decks were the only slope angle to achieve greater than $65 \%$ plant coverage during the study period; none of the treatments achieved $100 \%$ plant coverage. Since water loss is tied to evapotranspiration and stormwater runoff retention, further investigation is necessary in order to better determine the effects of plant coverage on stormwater runoff reduction of the green roof modules.

Model residential green roof systems retained $42.1 \%$ of the precipitation at this field site that is similar to other studies with green roof models specifically designed for urban roofs. Therefore, in suburban residential areas where homeowners' association(s) and other local policies permit, residential green roof systems could become a possible stormwater management tool among the choices for runoff BMPs.

\section{REFERENCES}

Berndtsson, J. C. (2010) Green roof performance towards management of runoff water quantity and quality: A review. Ecological Engineering 36:351-360.

Bird, S., Harrison, J., Exum, L., Alberty, S., Perkins, C. (2002) Screening to identify and prevent urban stormwater problems: Estimating impervious area accurately and inexpensively. In: Proceedings for National Water Quality Monitoring Conference. Madison, WI.

Bliss, D. J., Neufeld, R. D., Ries, R. J. (2009) Stormwater runoff mitigation using a green roof. Environmental Engineering Science 26(2):407-417.

Carey, P. K. (2004) Residential green roof policy, strategies and tactics. In: Proc of the $2^{\text {nd }}$ North American Green Roof Conference: Greening rooftops for sustainable communities, Portland, OR.

Carter, T., Butler, C. (2008) Ecological impacts of replacing traditional roofs with green roofs in two urban areas. Cities and the Environment 1(2): Article 9, 17 pp.

Dunnett, N., Gedge, D., Little, J., Snodgrass, E. C. (2011) Small green roofs: low-tech options for greener living. Timber Press, Portland, OR. 
Getter. K. L., Rowe, D. B., Andresen, J. A. (2007) Quantifying the effect of slope on extensive green roof stormwater retention. Ecological Engineering 31:225-231.

Liesecke, H. J. (1998) Das retentionsvermögen von dachbegrünungen. Stadt und Grün 46 (5): 46-53.

Mentens. J., Raes, D., Hermy, M. (2003) Greenroofs as a part of urban water management. Water Resources Management II. Southampton, UK, pp 35-44.

Mentens, J., Raes, D., Hermy, M. (2006) Green roofs as a tool for solving the rainwater runoff problem in the urbanized $21^{\text {st }}$ century? Landscape and Urban Planning 77:217-226.

Oberndorfer, E., Lundholm, J., Bass, B. et al (2007) Green roofs as urban ecosystems: Ecological structures, functions, and services. BioScience 57:823-833.

Schade, C. (2000) Wasserrückhaltung und Abflußbeiwerte bei dünnschichtigen estensivbegrünungen. Stadt und Grün 49(2):95-100.

Simmons, M. T., Gardiner, B., Windhager, S., Tinsley, J. (2008) Green roofs are not created equal: The hydrologic and thermal performance of six different extensive green roofs and reflective and nonreflective roofs in a sub-tropical climate. Urban Ecosystems 11:339-348.

USEPA (2003) Protecting water quality from urban runoff. EPA 841-F-03-003, Washington, DC.

VanWoert, N. D., Rowe, D. B., Andresen, J. A., Rugh, C. L., Fernandez, R. T., Xiao, L. (2005) Green roof stormwater retention: Effects of roof surface, slope, and media depth. Journal of Environmental Quality 34:1036-1044.

Villarreal E. L., Bengtsson, L. (2005) Response of a Sedum green-roof to individual rain events. Ecological Engineering 25:1-7.

Villarreal, E. L. (2007) Runoff detention effect of a sedum green roof. Nordic Hydrology 38:99-105. 